\title{
GAMBARAN FAMILY CARE GIVER BURDEN DALAM MERAWAT ANGGOTA KELUARGA DENGAN SKIZOFRENIA DI WILAYAH KERJA PUSKESMAS SUTOJAYAN KABUPATEN BLITAR (Overview of Family Care Giver Burden in Treating Schizophrenia with Family Members In the Work Area Health District Sutojayan Blitar)
}

\author{
Nawang Wulandari \\ STIKes Patria Husada Blitar \\ email: na_wul23@yahoo.co.id
}

\begin{abstract}
When someone is diagnosed with positive schizophrenia, there will be changes toward their life. Patients who previously have the ability to perform daily activities, in this conditions will always need help and assistance in fulfilling their life, especially the family members who are in charge in the caring. Various changes will certainly have impact on the patients themselves and for those around them, especially their family care giver. Care giver are expected to use most of their time to care and to provide social support for the sake of better conditions. This research aimed to describe the family care giver burden in the caring of their family members with schizophrenia in Puskesmaas Sutojayan Blitar. The research design used descriptive approah with purposive sampling. The total sample was 24 respondents. The data collectionused questionnaires. The results showed that 10 people (41.7\%) of the Family Care giver experiencing hard burden and average burden in the care of family members with schizophrenia. People should have good understanding and concern so that there would be negative stigma in people with schizophrenia so that the burden of the care giver is not increase because of the social burden obtained. When this kind of things were done, it would reduce the risk of relapse in people with scizofrenia
\end{abstract}

\section{Keywords: Family Care Giver Burden, Skizofrenia}

Abstrak: Saat seseorang positif didiagnosis skizofrenia, maka berbagai perubahan akan banyak terjadi. Penderita yang sebelumnya mempunyai kemampuan untuk melakukan kegiatan sehari-hari, pada kondisi seperti ini akan selalu memerlukan bantuan dan pertolongan dalam memenuhi kehidupannya khususnya kepada anggota keluarga yang peduli terhadapnya. Berbagai perubahan tentu akan berdampak pada pasien sendiri maupun bagi orang-orang disekitarnya terutama care giver keluarga yang merawatnya. Care giver dituntut menggunakan sebagian besar waktunya untuk merawat dan memberikan dukungan sosial demi kondisi yang lebih baik. Penelitian ini bertujuan untuk mengetahui gambaran family care giver burden dalam merawat anggota keluarga dengan skizofrenia di Wilayah Kerja Puskesmaas Sutojayan Kabupaten Blitar. Desain penelitian deskriptif dengan purposive sampling. Jumlah sampel 24 responden. Pengumpulan data menggunakan kuesioner. Hasil penelitian menunjukkan bahwa Family Care giver mengalami beban berat dan sedang dalam merawat anggota keluarga dengan skizofrenia yaitu masingmasing sebanyak 10 orang $(41,7 \%)$. Masyarakat hendaknya memiliki pemahaman dan kepedulian serta tidak memberikan stigma negatif pada orang dengan skizofrenia sehingga beban yang dirasakan care giver tidak semakin berat karena beban sosial yang didapat. dimana jika hal ini dilakukan juga akan menekan resiko kekambuhan pada orang dengan skizofrenia.

Kata Kunci: Family Care Giver Burden, Skizofrenia 
Skizofrenia merupakan suatu penyakit yang secara umum bersifat kronis dan menahun akibat ketidakseimbangan neurotransmiter dopamin. Ketika seseorang positif didiagnosis skizofrenia, maka berbagai perubahan akan banyak terjadi. Penderita yang sebelumnya mempunyai kemampuan untuk melakukan kegiatan sehari-hari, pada kondisi seperti ini akan selalu memerlukan bantuan dan pertolongan dalam memenuhi kehidupannya khususnya kepada anggota keluarga yang peduli terhadapnya (Kusumawati \& Hartono, 2010).

Hasil penelitian menunjukkan bahwa gangguan mental mengakibatkan beban cukup besar yaitu 8,1 persen dari global burden of disease (GDB) melebihi beban yang diakibatkan oleh penyakit tuberkulosis dan kanker. Dari 8,1 persen GDB yang ditimbulkan oleh gangguan neuropsikiatris, gangguan depresi memberikan beban terbesar, yaitu 17,3 persen, sedangkan gangguan psikosis memberikan beban 6,8 persen (Yosep, 2010 dalam Hamilasari, 2014). Sedangkan untuk wilayah kerja Puskesmas Sutojayan sendiri ada 25 penderita skizofrenia dimana beberapa keluarga menyatakan kurang mampu untuk melakukan perawatan.

Keluarga yang salah satu anggota keluarganya mengalami skizofrenia maka secara tidak langsung mereka juga akan ikut terasing dari lingkungannya, diremehkan dan menjadi bahan pergunjingan di masyarakat yang pada akhirnya sikap masyarakat terhadap keluarga tersebut akan berdampak juga pada status sosial ekonomi keluarga. Hal ini jugalah yang akan mempengaruhi hubungan keluarga dengan anggota keluarga mereka yang mengalami skizofrenia, klien skizofrenia akan dikucilkan karena dianggap telah membawa malapetaka untuk keluarga (Saseno dalam Nurhayati, 2008).

Beban keluarga yang dirasakan oleh keluarga dengan anggota keluarga yang mengalami skizofrenia yaitu berhubungan dengan perawatan termasuk biaya pengobatan, tanggung jawab untuk mengawasi kondisi mental, stigma yang muncul dari hasil interaksi dengan masyarakat, serta distress emosional akibat dari tanda dan gejala yang dialami oleh anggota keluarga dengan skizofrenia (McDonell, et al dalam Nuraenah, 2012). Utami (2011) mengatakan bahwa proses perawatan anggota keluarga dengan skizofrenia yang bertahun-tahun tidak jarang menimbulkan rasa jenuh dan bosan bagi family care giver, terutama apabila peran family caregiver hanya satu orang sehingga tidak dapat beristirahat dan melakukan kontrol maksimal terhadap anggota keluarga dengan skizofrenia. Beban psikologis lain yang dirasakan oleh keluarga adalah mereka ingin pergi, marah terhadap anggota keluarga yang menderita skizofrenia dan tuhan serta merasa bersalah karena memikirkan segala ketidaknyamanan yang dirasakan. Caregiver dituntut menggunakan sebagian besar waktunya untuk merawat dan memberikan dukungan sosial demi kondisi yang lebih baik. Dimana family burden ini dapat berpengaruh pada kondisi kesehatan caregiver sendiri.

Penelitian ini bertujuan untuk mengetahui gambaran family care giver burden dalam merawat anggota keluarga dengan skizofrenia di Wilayah Kerja Puskesmaas Sutojayan Kabupaten Blitar.

\section{BAHAN DAN METODE}

Penelitian ini merupakan penelitian deskriptif yang dilaksanakan di Wilayah Kerja Puskesmas Sutojayan Kabupaten Blitar pada tanggal 25-30 April 2016. Populasi dalam penelitian ini adalah keluarga yang mempunyai anggota keluarga dengan skizofrenia sebanyak 25 orang. Tehnik pengambilan sampel yang digunakan dalam penelitian ini adalah purposive sampling, dengan jumlah sampel yang didapatkan 24 responden.

Instrumen yang digunakan untuk melihat family care giver burden diadaptasi dari American Family Phsycian (2002) dan kuesioner penelitian Suwardiman (2011) dimana telah dimodifikasi oleh peneliti, yang terdiri dari 12 nomor (6 poin beban obyektif dan 6 poin beban subyektif).

\section{HASIL PENELITIAN}

Terbanyak responden berusia 40-47 tahun, dengan jenis kelamin sebagian besar responden perempuan. Untuk jenis pekerjaan responden bekerja petani, status perkawinan sebagian besar responden telah menikah yaitu sebanyak 18 orang. Sedangkan untuk tingkat pendidikan responden adalah SMP yaitu sebanyak 8 orang.

Dapat dilihat bahwa Family Care giver mengalami beban berat dan sedang dalam merawat anggota keluarga dengan skizofrenia yaitu masing-masing sebanyak 10 orang $(41,7 \%)$.

\section{PEMBAHASAN}

Hasil penelitian menunjukkan bahwa Family Care giver mengalami beban berat dan sedang dalam merawat anggota keluarga dengan skizofrenia yaitu masing-masing sebanyak 10 orang $(41,7 \%)$. 
Tabel 1. Karakteristik Family Care giver Berdasarkan Umur, Jenis kelamin, Pendidikan, Status perkawinan dan Pekerjaan di Wilayah Kerja Puskesmaas Sutojayan Kabupaten Blitar tanggal 25-30 April 2016

\begin{tabular}{clcc}
\hline Variabel & \multicolumn{1}{c}{ Kategori } & n & \% \\
\hline Umur (tahun) & $24-31$ & 4 & 16,7 \\
& $32-39$ & 4 & 16,7 \\
& $40-47$ & 7 & 29,2 \\
& $48-55$ & 4 & 16,7 \\
\multirow{5}{*}{ Jenis kelamin } & $56-66$ & 5 & 20,8 \\
& Laki-laki & 10 & 41,7 \\
Pendidikan & Perempuan & 14 & 58,3 \\
& Tidak sekolah & 3 & 12,5 \\
& SD & 7 & 29,2 \\
& SMP & 8 & 33,3 \\
\multirow{5}{*}{ Status } & SMA & 6 & 25 \\
& Janda/duda & 6 & 25 \\
Pekerjaan & Menikah & 18 & 75 \\
& Tidak bekerja & 2 & 8,3 \\
& Wiraswasta & 10 & 41,7 \\
& Petani & 12 & 50 \\
\hline
\end{tabular}

Tabel 2. Distribusi Family Care giver Burden dalam merawat anggota keluarga dengan skizofrenia di Wilayah Kerja Puskesmaas Sutojayan Kabupaten Blitar tanggal 25-30 April 2016

\begin{tabular}{clcc}
\hline No & Beban Keluarga & Frekuensi & \% \\
\hline 1 & Ringan & 4 & 16,7 \\
2 & Sedang & 10 & 41,7 \\
3 & Berat & 10 & 41,7 \\
\hline & Total & $\mathbf{2 4}$ & $\mathbf{1 0 0}$ \\
\hline
\end{tabular}

Persepsi beban yang berlebihan akan dirasakan oleh keluarga dalam merawat anggota keluarga dengan skizofrenia yaitu saat banyak permasalahan yang timbul akibat ketergantungan. Dampak negatif yang terjadi pada keluarga akan dirasakan sebagai beban subyektif dan beban obyektif. Salah satu beban subyektif yang paling sering dirasakan adalah kecemasan dan stigma, sedangkan beban obyektif yang paling sering dirasakan oleh responden adalah beban ekonomi dalam anggota keluarga dengan skizofrenia. Hasil penelitian menunjukkan bahwa responden merasa terbebani dengan beban obyektif. Hal ini sesuai dengan Varcarolis (2010) yang menyatakan bahwa beban yang paling berat yang dirasakan oleh keluarga adalah beban finansial dalam merawat anggota keluarga dengan skizofrenia. Dampak dari persepsi beban yang tidak dikelola dengan baik akan mempengaruhi produktivitas, kualitas hidup dan fungsi keluarga yang menjadi tidak optimal.

Keluarga dihadapkan pada banyak permasalahan yang mengakibatkan beban dalam keluarga menjadi berat. Banyaknya keterbatasan yang dimiliki oleh anggota keluarga dengan skizofrenia adalah stressor tersendiri bagi keluarga. Beban yang dihadapi juga juga bervariasi tergantung oleh beberapa faktor yaitu stigma masyarakat, pengetahuan, emosi dan kondisi ekonomi (Parish, et al, 2012). Dampak dari beban sendiri bervariasi tergantung dari mekanisme koping keluarga yang mengelola beban tersebut.

Beberapa keluarga menunjukkan beban berlebih ketika harus merawat anggota keluarga dengan skizofrenia, dampak yang keluarga rasakan akan berpengaruh terhadap kemampuan keluarga dalam merawat. Hal ini akan menyebabkan kualitas hidup anggota keluarga dengan skizofrenia, dimana sebelumnya terjadi penurunan pula dalam kualitas hidup keluarga atau care giver (Suliswati, 2005). Menurut teori beberapa faktor yang mempengaruhi persepsi beban keluarga adalah tingkat pendidikan dan penghasilan keluarga. Tingkat pendidikan yang tinggi akan mempengaruhi kemampuan keluarga dalam merawat anggota keluarga dengan skizofrenia, termasuk juga pengambilan keputusan untuk menggunakan sarana pelayanan kesehatan dan pendidikan (Notoatmodjo, 2008). Tingkat pendidikan responden dalam penelitian yang digambarkan pada Tabel.1 sebagian besar adalah SMP sebanyak 33,3\%. Pengetahuan yang baik dapat membantu keluarga dalam perawatan anak dengan permasalahan yang cukup kompleks (McDonald, Wiczorek \& Walker, 2004), sehingga adaptasi terhadap konsekuensi 
perawatan anak juga menjadi lebih baik yang tentunya akan berdampak pada persepsi beban.

Faktor yang lain adalah kondisi ekonomi yang juga menyebabkan persepsi beban keluarga yang dirasakan menjadi lebih berat (Parish et al, 2012). Keputusan keluarga untuk memberikan yang terbaik pada anggota keluarga dengan skizofrenia terkadang terhambat oleh penghasilan yang minim termasuk untuk kesehatan dan pendidikan anak, sehingga beberapa keluarga sering mengabaikan kesehatan dan pendidikan untuk perkembangan anggota keluarga dengan skizofrenia. Pada penelitian ini 50\% responden mempunyai penghasilan tidak menentu karena bekerja sebagai petani. Pada penelitian ini rata-rata anggota keluarga yang lain tidak dapat membantu mencari nafkah tambahan karena harus menunggu dan merawat anggota keluarga dengan skizofrenia

Pada dasarnya care giver sendiri sebenarnya membutuhkan dukungan dari orang lain terutama dari pihak keluarga sendiri untuk bersama-sama memecahkan masalah yang dialami sehingga perawatan anggota keluarga dengan skizofrenia menjadi lebih ringan jika dilakukan bersama dan tidak hanya dibebankan pada care giver saja dalam hal ini paling banyak oleh ibu. Hal ini sesuai dengan literatur yang menyatakan beban keluarga dapat ditekan dengan pemberian sistem dukungan sosial melalui sesama keluarga yang memiliki anggota keluarga dengan skizofrenia atau seorang pemberi perawatan kesehatan (Videback, 2008).

\section{SIMPULAN DAN SARAN}

\section{Simpulan}

Family care giver merupakan suatu peran yang tidak mudah untuk dijalani. Banyak masalah yang dihadapi selama merawat anggota keluarga dengan skizofrenia diantaranya yaitu mendapat perlakuan dan sikap negatif dari lingkungan, merasakan dampak dari merawat anggota keluarga dengan skizofrenia menanggung beban finansial untuk pengobatan dan memenuhi kebutuhan sehari-hari. Care giver sebenarnya membutuhkan dukungan dari orang lain atau anggota keluarga lain untuk bersama-sama merawat anggota keluarga yang mengalami skizofrenia agar beban yang dirasa menjadi lebih ringan.

\section{Saran}

Masyarakat hendaknya memiliki pemahaman dan kepedulian serta tidak memberikan stigma negatif pada orang dengan skizofrenia sehingga beban yang dirasakan care giver tidak semakin berat karena beban sosial yang didapat. dimana jika hal ini dilakukan juga akan menekan resiko kekambuhan pada orang dengan skizofrenia

\section{DAFTAR RUJUKAN}

American Family Physician. 2002. Volume 65 nomor 11/ juni.

Badan Penelitian dan Pengembangan Kesehatan Departemen Kesehatan RI. 2007. Laporan Nasional Riset Kesehatan Dasar. diambil dari www. riskesdas. litbang depkes. go.id. diakses tanggal 2 Februari 2015.

Hamilasari. 2014. Terapi Psikoedukasi Keluarga terhadap Kemampuan Keluarga dalam Merawat Klien dengan Skizofrenia di Rumah Sakit Jiwa Pemerintah Aceh. Jurnal Pendidikan dan Praktik Keperawatan 1(2). 97-211.

Kusumawati, F., Hartono, Y. 2010. Buku Ajar Keperawatan Jiwa. Jakarta: Salemba Medika.

Nurhayati. 2008. Hubungan Antara Pengetahuan dan Dukungan Keluarga dengan Frekuensi Kambuh Penderita Skizofrenia di Rumah Sakit Gondohutomo Semarang. Jurnal keperawatan 1(1).

Nuraenah. 2012. Hubungan Dukungan Keluarga dan Beban Keluarga dalam Merawat Anggota dengan Riwayat Perilaku Kekerasan di RS Islam Klender Jakarta Timur. Jurnal Keperawatan 2(1).

Notoatmodjo, S. 2010. Metodologi Penelitian Kesehatan. Jakarta: Rineka Cipta.

Parish, Susan, L., et al. 2012. State-Level Income Inequality and Family Burden of US Families Raising Children with Special Health Care Needs Social Science and Medicine. 74. 399-407.

Suliswati. 2005. Konsep Dasar Keperawatan Kesehatan Jiwa. Jakarta: EGC.

Suwardiman. 2011. Hubungan Antara Dukungan Keluarga dengan Beban Keluarga untuk Mengikuti Regimen Terapeutik pada Keluarga Klien Halusinasi RSUD Serang.Tidak dipublikasikan.

Utami, W.N. 2011. Hubungan antara pengetahuan tentang skizofrenia dan strategi koping dengan beban psikologis pada family care giver orang dengan skizofrenia. Gempar: Jurnal Ilmiah Keperawatan No.2 Vol 1.

Varcarolis, E.M., dan Halter, M.J. 2010. Foundations of psychiatric mental health nursing: a clinical approach, (6th ed). St. Louis, Missouri: Saunders Elsevier.

Videbeck, S.L. 2008. Buku Ajar Keperawatan Jiwa Alih Bahasa Renata Komalasari, Alfrina, Hany. Editor Bahasa Indonesia, Pamilih Eko Karyuni. Jakarta: ECG. 